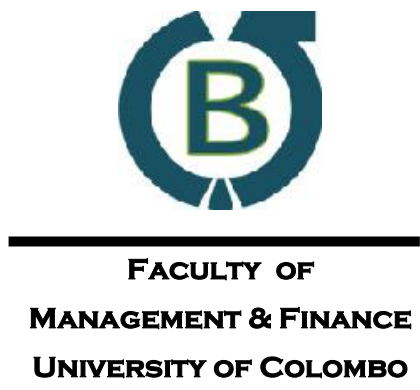

DOI: http://doi.org/10.4038/cbj.v6i2.26
Colombo

Business

Journal

Vol. 06, No. 02, December, 2015
International Journal

of Theory \& Practice

\title{
Concepts and Implications of Theory of Co-production
}

\author{
Ruwan Abeysekera ${ }^{1}$
}

Executive Business Centre, Bournemouth University, UK

\begin{abstract}
The purpose of this paper is to present the concepts of co-production discussed in previous literature and to discuss its implications on research and practice. This is a theoretical paper. It identifies that the extant literature in co-production presents a number of research gaps that can be addressed in future research. These gaps exist in the areas of collective co-production, dyadic relationships and contextual factors. Moreover, the practicing managers and the policy makers can also use co-production concepts identified in this paper to implement in their programmes which offer diverse benefits to the programmes and the clients.
\end{abstract}

Keywords: Co-Production, Collective Co-production, Collaborative Co-production, Partial Employees

\section{Introduction}

The recent renaissance of co-production, fuelled by the paper on service dominant logic by Vargo and Lusch (2004) has spawned a revival of interest in the subject matter (Chen, Tsou, \& Ching, 2011; Cheung \& To, 2011; Etgar, 2008; Peters, Bodkin, \& Fitzgerald, 2012). The literature on coproduction highlights the importance of active participation by the client in service production and delivery (Parks et al., 1981). The concept of co-production can be applied in industrial, service, and public sectors as it offers numerous benefits to both the service providers and the clients (Auh, Bell, McLeod, \& Shih, 2007; Cepiku \& Giordano, 2014; Fitzsimmons, 1985; Rice, 2002). For example due to a client's involvement (i.e., co-production) in service production, the service provider can bring down its costs (e.g., in the supermarkets, clients use self-help counters, so that supermarkets do not have to employ many client contact staff) and in turn clients being co-producers can experience independence, convenience and enjoyment (e.g., by using self-help counters, clients do not have to depend on the counter staff, they enjoy by paying by themselves and it is convenient as they do not have to be in long queues) and sometimes cost reduction (e.g. reserving an air ticket from the computer at home, the clients do not have to spend time and money to visit a travel agent to buy a ticket). While the co-production literature highlights the active participation of clients in service production, it also identifies the importance of service provider's involvement in service production with clients as there should be joint efforts between two parties in co-production (Parks et al., 1981;

${ }^{1}$ rabeysekera@bournemouth.ac.uk 
Rice, 2002). In other words, staff of the service provider have to engage with clients in service production.

The extant co-production literature presents a number of gaps and therefore the studies are needed to fill these gaps (Cepiku \& Giordano, 2014; Humphreys, 2008; Rice, 2002). For example there are limited studies made on collective co-production, co-production focusing on dyadic relationships between the firm's customer contact staff and customers and contextual factors that influence coproduction. Thus the purpose of this article is to identify these gaps in the literature so that future studies can focus on these and further present co-production concepts to the practitioners and the policy makers to implement in their programmes. The remainder of this article is organized as follows. Firstly, the paper introduces co-production. Secondly it discusses the key concepts of co-production. Thirdly it discusses the significance of co-production in the modern era and the key studies made in co-production, fourthly, the key literature on co-production is summarised in a table. Finally, it discusses conclusions, implications and agenda for future research.

\section{Co-production as a Concept}

\subsection{Origin of the Concept of Co-production}

The concept of co-production was originally developed by a workshop in Political Theory and Policy Analysis at Indiana University in 1973. Originally the concept of co-production related to the clients' or citizens' involvement in production (i.e., direct user involvement either in public or private sectors). This concept created a great enthusiasm among public administration scholars in the United States of America (USA) in the 1970s and 1980s (Parks et al., 1981).

Scholars argued that citizens as clients would receive an effective and efficient service from the professional staff employed by large bureaucratic agencies. After studying police services in the USA they found out that a centralized police department was unable to provide a better direct service to the clients, namely citizens (Ostrom, 1999). Hence they realized that not only the service provider but also the client needs to collaborate in the production. Further they also realized that the production of service as opposed to a good was difficult without the active participation of those receiving the service (Ostrom, 1999). Thus the term of co-production focuses on the individuals and groups in the production of services at the micro levels but it could have an impact on both the meso and the macro levels of the society (Ostrom, 1999).

According to Parks et al. (1981) co-production involves joint efforts between two parties who jointly determine the output of their collaboration. Here two parties means the consumer and the producer. In co-production, contrary to the passive role played by the consumer in the production, the efforts of the consumers are central to the production of the output (Rice, 2002).

The concept of co-production was initially studied in the context of industrial and service markets. Further co-production was originally discussed in terms of economic efficiency gained from collaborating with a customer in a business to business context resulting in competitive advantage (Fitzsimmons, 1985). In the 1990s scholars began to discuss the use of the co-production concept in consumer markets. In consumer markets, the emergence of 'customizing consumer' was witnessed with reference to those who take an active role in the production process (Firat, 1991; Firat \& Venkatesh, 1993;; Firat, Dholakia \& Venkatesh, 1995; Firat, Shultz, \& Clifford, 1997). In recent times, the work of Prahalad and Ramaswamy (2000; 2002; 2004) and, Vargo and Lusch $(2004,2006)$ 
on value co-creation and service dominant logic of marketing as a new school of thought has driven the idea of co-production. Until recently the dominant thinking was that customer value creation accompanies the product (Goods Dominant logic, G-D). However, Vargo and Lusch (2004) proposed the Service Dominant (S-D) Logic in which service provision rather than goods is the basis of economic exchange. These authors argue that value does not exist solely in the finished good but value is defined and created in co-production with the consumer as well (Vargo \& Lusch, 2006, p. 10). They propose that goods are part of distribution in the service provision and the customer is always a co-producer. Moreover their S-D logic identifies how customer collaboration affects the coproduction and how it brings about benefits such as lower costs, customized service offerings and increased productivity.

Marketing theory encourages service providers and customers to interact and customers to participate in the service production process (Auh et al., 2007; Lusch, Vargo \& O'Brien, 2007; Vargo \& Lusch, 2004). Etgar (2008) describes co-production as customers participating in the performance of various activities in the production process and that co-production encompasses all co-operation formats between the customer and the service provider.

\section{Key Concepts in Co-production}

This section discusses the key concepts derived from the literature relating to the concept of coproduction. Thus it discusses concepts including two forms of co-production, level of customer participation in co-production, three factors needed for co-production of a service, customers as partial employees, client affective commitment, self serving bias, self efficacy, socialization programmes, factors relating to client contact staff and clients that affect coproduction, influence of contextual factors on co-production, sustainability of co-production and, co-production outcomes. These concepts have been selected on the basis that they would 1) illuminate the reader about key concepts in co-production 2) identify the research gaps and 3) make practitioners aware about the applications of co-production in their organizations.

\subsection{Two Forms of Co-production: Collaborative Co-production and Collective \\ Co-production}

Co-production can take two forms: collaborative and collective co-production (Humphreys, 2008). Collaborative co-production refers to the partnership between the company and the consumers to create a service or a product, whereas collective co-production refers to the interaction between consumers to produce a product or service or product/service alterations independent of company and input and stewardship (Humphreys, 2008). In collaborative co-production the company works with the consumer in various stages of the value chain (i.e., conceptualization, design, production, post purchase service) to produce a product. In contrast, collective co-production fits in to the other end of the continuum and the consumer works independently from the service provider and may seek the assistance and advice from other consumers to produce a product (Peters et al., 2012). The extant literature (Auh et al., 2007; Bettencourt, Ostrom, Brown, \& Roundtree, 2002; Rice, 2002) focuses mainly on collaborative co-production and there are few studies done using collective co-production especially in a business discipline. Hence future research can be done focusing on collective coproduction. 


\subsection{Levels of Customer Participation in Co-production}

There are 3 levels of customer participation in service experience (Bitner, Faranda, Hubbert \& Zeithaml, 1997):

1. Low (e.g. fast food restaurant)

2. Moderate (e.g. hair cut)

3. High (e.g. counselling, training)

As shown in Table 1 below depending on the nature of the service, the level of customer participation varies and so does the level of co-production. For certain services like a fast food restaurant, the customer's participation in service is low. A customer may have to order the food he wants and then purchase. But for a service like a haircut, the customer has to exert effort by visiting the barber, giving instructions and be patient whilst the hair cutting is taking place, thus a moderate level of customer participation is required. In contrast, when it comes to services like counselling and training, the customer needs to be able to be highly involved in the service experience. For example, a trainer may give instructions but the trainee (customer) needs to be able to attend training, grasp the knowledge and skills, and finally implement what is learnt. Thus according to Bitner et al. (1997), customer participation in service production varies with the type of the product and therefore implies that a different degree of customer effort is expected in co-production based on the type of the product.

Table 1: Levels of Customer Participation

\begin{tabular}{|c|c|c|}
\hline $\begin{array}{l}\text { Low. Customer Presence } \\
\text { Required During Service } \\
\text { Delivery }\end{array}$ & $\begin{array}{l}\text { Moderate. Customer Inputs } \\
\text { Required for Service Creation }\end{array}$ & $\begin{array}{l}\text { High. Customer Co-creates } \\
\text { the Service Product }\end{array}$ \\
\hline Products are standardised & $\begin{array}{l}\text { Client inputs customise a } \\
\text { standard service }\end{array}$ & $\begin{array}{l}\text { Active client participation } \\
\text { guides the customised service }\end{array}$ \\
\hline $\begin{array}{l}\text { Service is provided regardless } \\
\text { of any individual purchase }\end{array}$ & $\begin{array}{l}\text { Provision of service requires } \\
\text { customer purchase }\end{array}$ & $\begin{array}{l}\text { Service cannot be created apart } \\
\text { from the customer's purchase } \\
\text { active participation }\end{array}$ \\
\hline $\begin{array}{l}\text { Payment may be the only } \\
\text { required customer input }\end{array}$ & $\begin{array}{l}\text { Customer inputs (information, } \\
\text { materials) are necessary for an } \\
\text { adequate outcome, but the } \\
\text { service firm provides the } \\
\text { service }\end{array}$ & $\begin{array}{l}\text { Customer inputs are mandatory } \\
\text { and co-create the outcome }\end{array}$ \\
\hline$\frac{\text { Examples }}{\text { End consumer }}$ & & \\
\hline $\begin{array}{l}\text { Air line travel } \\
\text { Fast food restaurant }\end{array}$ & $\begin{array}{l}\text { Hair cut } \\
\text { Annual physical exam }\end{array}$ & $\begin{array}{l}\text { Marriage counselling } \\
\text { Weight reduction programme }\end{array}$ \\
\hline $\begin{array}{l}\text { Business to business customer } \\
\text { Pest control } \\
\text { Maintenance service }\end{array}$ & $\begin{array}{l}\text { Agency created advertising } \\
\text { campaign } \\
\text { Payroll service }\end{array}$ & $\begin{array}{l}\text { Management consulting } \\
\text { Executive management seminar }\end{array}$ \\
\hline
\end{tabular}

Source: Hubbert (1995) 


\subsection{Three Factors Needed for Co-production of a Service}

Three customer related factors are imperative to effective co-production: Perceived clarity of the task/role, ability or competence and, motivation (Bettencourt et al., 2002; Lengnick-Hall, Claycomb, \& Inks, 2000; Lengnick-Hall, 1996; Lovelock \& Young, 1979; Meuter, Bitner, Ostrom, \& Brown, 2005).

Task clarity refers to the extent which customers understand what is required of them in obtaining service. The clearer a customer's role expectations, the greater is the likelihood that their contributions will lead to improved service outcomes (Mills, Chase, \& Margulies, 1983). Rodie and Kleine (2000) mention four types of role clarity, namely customer's own experience with a particular service provider, customer's experience with the service provider's direct competitors, customer's experience with similar service contexts and the behaviour of other customers.

Customer ability refers to the quality of input a customer provides to the service production process. A customer's useful and timely customer contributions enhance the co-production output (Schneider \& Bowen, 1995). According to Auh et al. (2007) and Moorthy, Ratchford and Talukdar (1997), ability is defined as expertise and they believe that a customer with experience (i.e., expertise) with the service is better equipped to make valuable contributions to the production of service and thus co-production. Rodie and Kleine (2000) provide a broad definition of ability which includes knowledge, skills and experience of the customer. Further customer self-efficacy (i.e. perceived ability (belief)) to perform a task can also be discussed under customer ability (Bandura, 2001), and customer self-efficacy improves the co-production (Ford \& Dickson, 2012). Rodie and Kleine (2000) mention three types of benefits that motivate customer participation in service namely efficiency in service process, efficiency of the service outcome and psychological benefits (e.g., novelty, enjoyment and increased perceived control).

\subsection{Customers as Partial Employees}

The studies show that organizations view service customers as partial employees (Bettencourt et al., 2002; Bowen, 1986; Mills \& Morris, 1986; Mills et al., 1983). The customer provides inputs in terms of quantity and quality as an employee for the service production and delivery. For example, in management consultancy if the customer gives required information to the management consultancy firm, then it can help the customer better. Thus by considering the customer as a partial employee, the consultancy firm can provide prior training to the customers enabling them to give required information. Considering the customer's role as a partial employee, number of studies (Kotze \& Du Plesis, 2003; Bitner et al., 1997) show that customers should be given prior socialisation and training similarly to internal employees so that customers become better co-producers (Kotze \& Du Plesis,2003).

\subsection{Client Affective Commitment}

Consistent with the views of clients as partial employees, affective commitment can be defined as customer attachment to, identification with, and involvement in the organization (Meyer \& Allen, 1997). Affective commitment is based on emotional attachment of the client to an organization with the sense of belonging or being part of the family. The empirical studies show that clients' affective commitment relates to positive co-production (Chen et al., 2011; Auh et al., 2007). The findings of Auh et al. (2007) on co-production and customer loyalty in financial services reveals that clients' affective commitment to organization impacts on co-production. Moreover the study of Chen et al. 
(2011) on information service industry focusing on co-production and service innovation also shows that service partner's affective commitment enhances co-production.

\subsection{Self-serving Bias}

Studies show that customers become better co-producers when they are given the autonomy to take part in service production so that self-serving bias can be minimized (Bendapudi \& Leone, 2003; Knee \& Zukerman, 1996). Knee and Zuckerman (1996) define autonomy as a situation that fosters choices and a sense of freedom. The self-serving bias refers to a person's tendency to claim more responsibility than a partner for success and less responsibility for failure in a situation where an outcome is produced jointly (Wolosin, Sherman, \& Till, 1973).

Using an individual differences perspective, Knee and Zuckerman (1996) show that people who have a high autonomy orientation are less subject to the self-serving bias than those who have a low autonomy orientation. Further, researchers demonstrate that self-serving bias could be reduced when clients have a strong partnership with partners (Bendapudi \& Leone, 2003; Campbell \& Sedikides, 1999). Thus the interpersonal relationship between the client and the service provider could reduce the self-serving bias and thereby make clients better co-producers.

\subsection{Self-efficacy}

Studies show that clients' self -efficacy improves co-production (Ford \& Dickson, 2012; Van Beuningen, de Ruyter, \& Wetzels, 2010). According to Bandura (1997, 2001), self-efficacy is an individual's belief in their capability to perform a task.

Successful organizations not only want to understand the willingness and actual ability of customers to co-produce but also customers' belief that they can successfully perform the tasks required (Ford and Dickson, 2012; Van Beuningen et al., 2010). In other words they want to improve the self-efficacy of the customers. Organizations use self-efficacy strategies to improve co-production. Study by Ford and Dickson (2012) on enhancing customer efficacy in co-producing service experience shows that organizations can train their employees to encourage the customers to coproduce. Employees need to be alert and empathetic to enable customer success in co-production requirements. Further, organizations can improve self-efficacy of customers by asking customers to face similar situations before the real life co-production occurs (e.g., no risk trials) so that customers can evaluate how their skills match up to the expectations (Ford \& Dickson, 2012).

\subsection{Socialisation Programmes}

Studies done on education, financial services, grocery retailing and charitable organizations show that socialisation programmes offered by organizations improve the client participation in service and make clients, better co-producers (Kotze \& Du Plesis, 2003; Bettencourt, 1997; Kelley, Skinner, \& Donnelly, 1992). According to Kelly et al. (1992), organizational socialisation is the process by which an individual adapts and comes to appreciate the values, norms and required behavioural guidelines to direct their participation in service production and delivery. In fact, socialisation programmes improve a client's ability, role of clarity and motivation that are crucial for co-production (Kotze \& Du Plesis, 2003). Study by Kotze and Du Plesis (2003) students' co-production in tertiary education identified that student socialisation improves co-production of students by improving their ability, role of clarity, and motivation. 


\subsection{Factors Relating to Client Contact Staff and Clients that Affect Co-Production (Dyadic Relationships)}

Few studies have been conducted on co-production in relation to dyadic relationship between client contact staff and clients in co-production. Rice (2002) investigates the dyadic relationship between incubator managers and entrepreneurs in his exploratory study on the co-production of business assistance in business incubators. Rice uses the definition of co-production given by Parks et al. (1981) to investigate dyadic relationships. Guo and $\mathrm{Ng}$ (2011), in their study focusing on equipment based services examine the dyadic relationships between the personnel of two firms. These studies show that co-production between individuals improves the performance of firms.

It is important to identify factors relating to client contact staff of service provider and clients that influence co-production. The literature (Auh et al., 2007; Bettencourt et al., 2002; Rice, 2002) reveals that expertise, communication, and interpersonal relationships of client contact staff and clients, improve co-production.

Studies show that the expertise of client contact staff enhances co-production (Rice, 2002). The expertise of client contact staff refers to the knowledge and experience of them in providing services. Rice's (2002) study on business incubators show that incubator managers (i.e., client contact staff) with better educational qualifications (i.e., knowledge) and experience can help improve the ability of entrepreneurs and thereby enhance co-production. Further the studies reveal that when clients have expertise in terms of being familiar with firm's services then those clients can co-produce better with firm compared to clients who do not have experience (Auh et al., 2007). The studies also show that communication between client contact staff and clients improve the incidence of co-production (Auh et al., 2007; Bettencourt et al., 2002). Moreover, communication between service provider and client also improves their willingness to share information and hence further increase the incidence of coproduction (Auh et al., 2007). The literature further shows that when a service provider (i.e., client contact staff) communicates openly with a client giving all the (required) information it improves the clarity of role of client to co-produce better (Auh et al., 2007). On the other hand a client also needs to provide information to the service provider to be able to co-produce better (Hsieh, Yen \& Chin, 2004; Bettencourt et al., 2002; Bitner et al., 1997). Moreover interpersonal relationship between client contact staff and clients improve co-production (Guo \& Ng, 2011). Interpersonal relationship improves the trust and satisfaction between parties and it helps parties to achieve co-production outcomes. Moreover studies show that inter- personal relationship reduces self- serving bias which improves co-production (Bendapudi \& Leone, 2003; Campbell \& Sedikides, 1999). Since there is a dearth of studies (Guo \& Ng, 2011; Rice, 2002) done concerning dyadic relationships, there is an opportunity for future research to be carried out in this area.

\subsection{Influence of Contextual Factors on Co-production}

Studies on co-production have largely focused on bilateral relationships between service providers and users and the overall impact of co-production services, ignoring how contextual factors such as the macro environment, proximate environment, elements of co-production management such as institutional design, and strategic management affect co-production (Cepiku \& Giordano, 2014; Verschuere, Brandsen, \& Pestoff, 2012). Thus there is a lacuna in the co-production literature that examines how contextual factors affect co-production. 


\subsection{Sustainability of Co-production}

The literature on co-production shows that small group interactions can facilitate sustainable coproduction (Pestoff, 2014, 2012). The members of groups meet each other for a collective action and therefore it enhances co-production. For example members in a client group formed by a Microfinance Institution (MFI) meet each other on a regular basis and with officers to sort out their problems relating to their small businesses resulting in sustainable co-production.

\subsection{Co-production Outcomes}

Co-production outcomes could vary depending on the setting (e.g.. incubator, health, solid waste collection). Further co-production outcomes may also change in terms of the co-production partners and sponsors and management. For example, in business incubator setting, co-production outcome for the co-production partners (i.e., entrepreneurs and incubator managers) would be business assistance. Business assistance is an intermediate outcome. However the sponsors and management of business incubator are more concerned with co-production outcomes that reflect broader socio economic impacts such as job creation, neighbourhood revitalization, technology transfer and improvement in the economic condition of disadvantaged minorities (Rice, 2002, Schroeder, 1990). Similar patterns could be observed in other examples of co-production such as anti-crime, solid waste collection, health service, education programmes, finance industry and such. (Auh et al., 2007; Cheung \& To, 2011).

\section{The Significance of Co-production in the Modern Era and Key Studies Conducted in Co-production}

As explained in the introductory section, the work of Vargo and Lusch (2004) on service dominant logic has made co-production a significant concept as it can be discussed under service dominant logic as opposed to goods dominant logic. Thus we can see studies being focused on coproduction under service dominant logic in recent times. For example, in 2011, Chen et al. used coproduction concept in IT industry and found out that co-production enhances the service innovation. Further Ford and Dickson (2012) discussed the importance of self-efficacy in co-production in service provision. Peters et al. (2012) researched application of collective co-production in manufacturing. Further in recent times co-production concept has widely been used in public management (Cepiku \& Giordano, 2014; Pestoff, 2014). Thus it can be seen that the concept of co-production is used in recent studies and hence its importance to research. Table 2 below presents key studies done on coproduction in chronological order. These crucial studies were selected based on the important concepts and the gaps in co-production that are discussed in this paper. In these key studies, Parks et al. (1981) define co-production as joint efforts between two parties who jointly determine the output of their collaboration. Parks et al. (1981) definition could be applied for dyadic relationships as it discusses relationships between two parties (i.e. consumer producer and regular producer). Bitner et al. (1997) in their study on co-production found that the customers who undergo training before the service is delivered co-produce effectively in the service provision and this study further highlights the level of customer participation in co-production based on different services. Gruen, Summers, and Acito (2000) conducted a study on co-production in insurance sector focusing on how members' commitment affects co-production and found out that members' affective commitment is positively correlated with the co-production. Rice (2002) investigated how dyadic relationships between incubator managers and entrepreneurs affect co-production and the findings revealed that allocation of time of incubator manager and readiness of entrepreneurs influence co-production. Bettencourt et al. (2002) proposed a co-production model for the knowledge based intensive services firms and the 
authors highlighted the importance of training clients considering them as partial employees and how firms should focus on client's ability, motivation and clarity of task to increase the incidence of coproduction. Bendapudi and Leone (2003) investigated the concept of self-serving bias in coproduction and found out that customers are subject to self-serving bias in co-production situation and self-serving bias is reduced when the customers have the autonomy. Kotze and Du Plesis's (2003) study focusing on education revealed that when educational institutions offer socialization programmes before the study programmes begin, the students tend to co-produce more. Hsieh et al. (2004) investigated the relationship between the customer participation and service provider's workload in their study on food restaurants in Taiwan. The study revealed that service providers needed to improve customers' ability, motivation and the clarity of task to increase co-production and customers' participation in service provision is positively related to the service providers' work load. Etgar (2008) in his conceptual paper developed a model for customer engagement in co-production and highlighted the importance of context (e.g. macro environment) in co-production. Auh et al. (2007) conducted a study on co-production in financial and medical service sectors and found out that the factors such as communication and customer expertise improve the co-production between the customer contact staff and the customers. Further this study revealed that enhanced co-production lead to better customer loyalty. Cheung and To's (2011) study on financial services found that coproduction plays a moderating role between the customers involvement in service and perceived service performance. The study shows that when there is a greater co-production, the customer involvement and perceived service performance increase. Guo and Ng' (2010) study on equipment based services focused on the dyadic relationships in co-production and the findings showed that inter-personal relationships between individuals of two firms enhance co-production.

\section{Summary of Key Literature on Co-Production}

Table 2 summarises the key literature on co-production from which the key concepts of coproduction have been derived for this paper.

Table 2: Summary of Key Literature on Co-Production

\begin{tabular}{|c|c|c|c|c|}
\hline Author(s) & Sector and Focus & Nature of Study & Findings and Conclusions & $\begin{array}{l}\text { Key Concepts } \\
\text { Derived from } \\
\text { the Study }\end{array}$ \\
\hline $\begin{array}{l}\text { Parks et al. } \\
\text { (1981) }\end{array}$ & $\begin{array}{l}\text { General, Identifying a } \\
\text { formula for co- } \\
\text { production }\end{array}$ & Conceptual & $\begin{array}{l}\text { Coproduction can be defined } \\
\text { as } \mathrm{Q}=\mathrm{cRP} \mathrm{CP}^{\mathrm{e}} \text { Where } \mathrm{Q}= \\
\text { Output, } \mathrm{RP}=\mathrm{Regular} \\
\text { Producer inputs, } \mathrm{CP}= \\
\text { Consumer Producer inputs, } \mathrm{c} \\
=\text { scaling factor, } \mathrm{d}, \mathrm{e}=\text { output } \\
\text { elasticities of each input. This } \\
\text { formula highlights the joint } \\
\text { efforts between two parties } \\
\text { who jointly determine the } \\
\text { output of their collaboration. }\end{array}$ & $\begin{array}{l}\text { Dyadic } \\
\text { relationships, co- } \\
\text { production } \\
\text { outcomes }\end{array}$ \\
\hline
\end{tabular}




\begin{tabular}{|c|c|c|c|c|}
\hline Author(s) & Sector and Focus & Nature of Study & Findings and Conclusions & $\begin{array}{l}\text { Key Concepts } \\
\text { Derived from } \\
\text { the Study }\end{array}$ \\
\hline $\begin{array}{l}\text { Bitner et al. } \\
\text { (1997) }\end{array}$ & $\begin{array}{l}\text { Health(USA), } \\
\text { Examines the role of } \\
\text { customers in creating } \\
\text { quality and } \\
\text { productivity in service } \\
\text { experiences }\end{array}$ & Case studies & $\begin{array}{l}\text { Customers who underwent } \\
\text { training are more } \\
\text { knowledgeable and need less } \\
\text { assistance. Monitoring } \\
\text { customer contribution by } \\
\text { encouraging them, giving } \\
\text { them a feedback and } \\
\text { rewarding them improve the } \\
\text { participation. The customers } \\
\text { are satisfied with their own } \\
\text { and the service provider's } \\
\text { outcomes as a result of } \\
\text { effective participation in } \\
\text { service delivery. }\end{array}$ & $\begin{array}{l}\text { Levels of } \\
\text { customer } \\
\text { participation in } \\
\text { co-production, } \\
\text { Socialization/self } \\
\text { efficacy }\end{array}$ \\
\hline $\begin{array}{l}\text { Gruen et al. } \\
(2000)\end{array}$ & $\begin{array}{l}\text { Insurance (USA), } \\
\text { Identifying members } \\
\text { commitment } \\
\text { (normative, affective } \\
\text { and continuance) } \\
\text { impact on co- } \\
\text { production and } \\
\text { member participation }\end{array}$ & $\begin{array}{l}\text { Quantitative } \\
2535 \text { responses } \\
\text { received. } \\
\text { Administrated } \\
\text { questionnaire } \\
\text { primarily to obtain } \\
\text { the data in addition } \\
\text { to some } \\
\text { exploratory } \\
\text { interviews } \\
\text { conducted. }\end{array}$ & $\begin{array}{l}\text { Normative and affective } \\
\text { commitments partially } \\
\text { mediate the effects on co- } \\
\text { production and member } \\
\text { participation }\end{array}$ & $\begin{array}{l}\text { Client affective } \\
\text { commitment }\end{array}$ \\
\hline Rice (2002) & $\begin{array}{l}\text { Business incubators } \\
\text { (USA), Understanding } \\
\text { the dyadic relationship } \\
\text { between the incubator } \\
\text { managers and } \\
\text { entrepreneurs through } \\
\text { co-production concept }\end{array}$ & $\begin{array}{l}\text { Empirical, } \\
\text { Multiple case } \\
\text { study }\end{array}$ & $\begin{array}{l}\text { The allocation of the time of } \\
\text { the incubator manager, the } \\
\text { intensity of intervention, the } \\
\text { breadth highlights the joint } \\
\text { efforts between two parties } \\
\text { who jointly determine the } \\
\text { output of their collaboration. }\end{array}$ & $\begin{array}{l}\text { Dyadic } \\
\text { relationships, co- } \\
\text { production } \\
\text { outcomes }\end{array}$ \\
\hline
\end{tabular}




\begin{tabular}{|c|c|c|c|c|}
\hline Author(s) & Sector and Focus & Nature of Study & Findings and Conclusions & $\begin{array}{l}\text { Key Concepts } \\
\text { Derived from } \\
\text { the Study }\end{array}$ \\
\hline $\begin{array}{l}\text { Bettencourt et } \\
\text { al. (2002) }\end{array}$ & $\begin{array}{l}\text { Knowledge Intensive } \\
\text { Based Services } \\
\text { (KIBS), Proposing a } \\
\text { model for client co- } \\
\text { production } \\
\text { management process. }\end{array}$ & $\begin{array}{l}\text { Qualitative, case } \\
\text { study based }\end{array}$ & $\begin{array}{l}\text { The model proposed by the } \\
\text { study can be applied for } \\
\text { various KIBS firms which } \\
\text { need tailor-made solutions. } \\
\text { The model illustrates the } \\
\text { considering clients as the } \\
\text { partial employees. Effective } \\
\text { co-production improves the } \\
\text { project success, client } \\
\text { satisfaction and competitive } \\
\text { advantage. }\end{array}$ & $\begin{array}{l}\text { Three factors } \\
\text { (i.e. ability, } \\
\text { motivation, } \\
\text { clarity of task) } \\
\text { that are needed } \\
\text { for co- } \\
\text { production of } \\
\text { service, } \\
\text { Customers as } \\
\text { partial } \\
\text { employees }\end{array}$ \\
\hline $\begin{array}{l}\text { Bendapudi } \\
\text { and Leone } \\
\text { (2003) }\end{array}$ & $\begin{array}{l}\text { Manufacturing and } \\
\text { services, Examining } \\
\text { the effects of customer } \\
\text { participation on } \\
\text { customer satisfaction } \\
\text { based on self-serving } \\
\text { bias. }\end{array}$ & $\begin{array}{l}\text { Quantitative, based } \\
\text { on two studies }\end{array}$ & $\begin{array}{l}\text { Findings show that a } \\
\text { customer who participates in } \\
\text { production is subject } \\
\text { to the self-serving bias and } \\
\text { that this bias is reduced when } \\
\text { a customer has a choice } \\
\text { (autonomy) of whether he or } \\
\text { she will participate } \\
\text { in production. }\end{array}$ & Self-serving bias \\
\hline $\begin{array}{l}\text { Kotze and } \\
\text { Plesis (2003) }\end{array}$ & $\begin{array}{l}\text { Education, Students as } \\
\text { co-producers in } \\
\text { education }\end{array}$ & Conceptual & $\begin{array}{l}\text { Presents a model which } \\
\text { explains how student } \\
\text { participation and } \\
\text { socialization contribute to co- } \\
\text { production. }\end{array}$ & Socialization \\
\hline $\begin{array}{l}\text { Hsieh et al. } \\
\text { (2004) }\end{array}$ & $\begin{array}{l}\text { Food Restaurants } \\
\text { (Taiwan), } \\
\text { examining the } \\
\text { relationship between } \\
\text { customer participation } \\
\text { and service provider's } \\
\text { workload }\end{array}$ & $\begin{array}{l}\text { Quantitative. Data } \\
\text { were collected } \\
\text { from } 293 \\
\text { customer contact } \\
\text { employees at } 64 \\
\text { restaurants in } \\
\text { Taiwan }\end{array}$ & $\begin{array}{l}\text { The findings indicate that } \\
\text { customer participation is } \\
\text { positively related service } \\
\text { provider's workload. }\end{array}$ & $\begin{array}{l}\text { Three factors } \\
\text { that are needed } \\
\text { for co- } \\
\text { production of } \\
\text { service }\end{array}$ \\
\hline Etgar (2008) & $\begin{array}{l}\text { Services, Indentify } \\
\text { stages in customer } \\
\text { engagement in co- } \\
\text { production }\end{array}$ & Conceptual & $\begin{array}{l}\text { Discusses the basic linkages } \\
\text { between co-production and } \\
\text { customization and presents } \\
\text { co-production as a dynamic } \\
\text { process which is composed } \\
\text { of five distinct stages. }\end{array}$ & $\begin{array}{l}\text { Importance of } \\
\text { Context }\end{array}$ \\
\hline
\end{tabular}




\begin{tabular}{|c|c|c|c|c|}
\hline Author(s) & Sector and Focus & Nature of Study & $\begin{array}{l}\text { Findings and } \\
\text { Conclusions }\end{array}$ & $\begin{array}{l}\text { Key Concepts } \\
\text { Derived from } \\
\text { the Study }\end{array}$ \\
\hline $\begin{array}{l}\text { Auh et al. } \\
\text { (2007) }\end{array}$ & $\begin{array}{l}\text { Financial and medical } \\
\text { services (USA), } \\
\text { Identifying the factors } \\
\text { enhancing the level of } \\
\text { co-production and } \\
\text { investigating the link } \\
\text { between co-production } \\
\text { and customer loyalty }\end{array}$ & $\begin{array}{l}\text { Empirical, } \\
\text { Quantitative } \\
\text { Sample consisted } \\
\text { of } 1197 \text { customers } \\
\text { from a large } \\
\text { multinational } \\
\text { financial services } \\
\text { organization and } \\
100 \text { patients from } \\
\text { medical services. } \\
\text { Data were } \\
\text { collected through a } \\
\text { self-administrated } \\
\text { questionnaires } \\
\text { sent. }\end{array}$ & $\begin{array}{l}\text { Customer expertise, } \\
\text { customer-advisor } \\
\text { communication, customer } \\
\text { affective commitment and } \\
\text { interactional justice are } \\
\text { identified as factors that have } \\
\text { an impact on the co- } \\
\text { production and in turn } \\
\text { customer loyalty }\end{array}$ & $\begin{array}{l}\text { Dyadic } \\
\text { relationships, } \\
\text { Three factors } \\
\text { needed for co- } \\
\text { production of } \\
\text { service, Co- } \\
\text { production } \\
\text { outcomes }\end{array}$ \\
\hline $\begin{array}{l}\text { Cheung and } \\
\text { To (2011) }\end{array}$ & $\begin{array}{l}\text { Financial services } \\
\text { (China), Identifying } \\
\text { the moderating role of } \\
\text { co-production between } \\
\text { customer involvement } \\
\text { and perceived service } \\
\text { performance }\end{array}$ & $\begin{array}{l}\text { Quantitative. } \\
\text { The study was } \\
\text { done for } 349 \\
\text { Chinese bank } \\
\text { customers. }\end{array}$ & $\begin{array}{l}\text { The relationship between } \\
\text { customer involvement and } \\
\text { perceived service } \\
\text { performance is stronger when } \\
\text { there is high co-production as } \\
\text { opposed to a low co- } \\
\text { production. }\end{array}$ & $\begin{array}{l}\text { Co-production } \\
\text { outcomes }\end{array}$ \\
\hline $\begin{array}{l}\text { Guo and } \mathrm{Ng} \\
\text { (2011) }\end{array}$ & $\begin{array}{l}\text { Equipment based } \\
\text { services(UK), Co- } \\
\text { production through } \\
\text { individuals between } \\
\text { two companies }\end{array}$ & $\begin{array}{l}\text { Empirical, } \\
\text { discourse analysis }\end{array}$ & $\begin{array}{l}\text { Co-production can be } \\
\text { enhanced through the } \\
\text { interpersonal relationships } \\
\text { between individuals of } \\
\text { service provider and } \\
\text { customer firms. With the } \\
\text { increased interpersonal } \\
\text { relationships, cooperation } \\
\text { could go from reciprocal to } \\
\text { communal. }\end{array}$ & $\begin{array}{l}\text { Dyadic } \\
\text { relationships }\end{array}$ \\
\hline
\end{tabular}




\begin{tabular}{|c|c|c|c|c|}
\hline Author(s) & Sector and Focus & Nature of Study & $\begin{array}{l}\text { Findings and } \\
\text { Conclusions }\end{array}$ & $\begin{array}{l}\text { Key Concepts } \\
\text { Derived from } \\
\text { the Study }\end{array}$ \\
\hline $\begin{array}{l}\text { Chen et al. } \\
\text { (2011) }\end{array}$ & $\begin{array}{l}\text { IT industry } \\
\text { (Taiwan), Exploring } \\
\text { the influence of } \\
\text { Business to Business } \\
\text { co-production on } \\
\text { service innovation }\end{array}$ & $\begin{array}{l}\text { Empirical, } \\
\text { Quantitative } \\
\text { Study was done on } \\
157 \text { questionnaires } \\
\text { received from the } \\
\text { IT firms. }\end{array}$ & $\begin{array}{l}\text { Co-production positively } \\
\text { influences service innovation } \\
\text { to a degree that depends on } \\
\text { the collaborative partner's } \\
\text { Compatibility and history of } \\
\text { business relations, affective } \\
\text { commitment, and expertise. } \\
\text { Moreover, the business' } \\
\text { innovation orientation } \\
\text { enhances (moderates) the } \\
\text { relationship between co- } \\
\text { production and service } \\
\text { innovation. }\end{array}$ & $\begin{array}{l}\text { Customer } \\
\text { affective } \\
\text { commitment }\end{array}$ \\
\hline $\begin{array}{l}\text { Ford and } \\
\text { Dickson } \\
\text { (2012) }\end{array}$ & $\begin{array}{l}\text { Service, Customer self- } \\
\text { efficacy in co- } \\
\text { production }\end{array}$ & Conceptual & $\begin{array}{l}\text { Customer self-efficacy is } \\
\text { important in service co- } \\
\text { production and thus the } \\
\text { service providers have to use } \\
\text { strategies such as employee } \\
\text { training and environmental } \\
\text { cues to enhance customer } \\
\text { self-efficacy. }\end{array}$ & $\begin{array}{l}\text { Customer self- } \\
\text { efficacy }\end{array}$ \\
\hline $\begin{array}{l}\text { Peters et al, } \\
(2012)\end{array}$ & $\begin{array}{l}\text { Manufacturing(USA), } \\
\text { Consumers search for } \\
\text { meaning and } \\
\text { fulfillment via } \\
\text { collective co- } \\
\text { production. }\end{array}$ & $\begin{array}{l}\text { Qualitative, Case } \\
\text { Study Method }\end{array}$ & $\begin{array}{l}\text { The findings reveal that } \\
\text { during the design stage the } \\
\text { consumers shaped their self } \\
\text { concept through social } \\
\text { inspiration, creative self } \\
\text { expression and primal sense. }\end{array}$ & $\begin{array}{l}\text { Collaborative } \\
\text { and collective } \\
\text { co-production }\end{array}$ \\
\hline $\begin{array}{l}\text { Cepiku and } \\
\text { Giordano } \\
\text { (2014) }\end{array}$ & $\begin{array}{l}\text { Public service } \\
\text { (Ethiopia), Co- } \\
\text { production in } \\
\text { developing countries }\end{array}$ & $\begin{array}{l}\text { Longitudinal case } \\
\text { study method }\end{array}$ & $\begin{array}{l}\text { Contextual and conceptual } \\
\text { conditions might change the } \\
\text { existing theoretical models. }\end{array}$ & Context \\
\hline
\end{tabular}




\begin{tabular}{lllll}
\hline Author(s) & Sector and Focus & Nature of Study & $\begin{array}{l}\text { Findings and } \\
\text { Conclusions }\end{array}$ & $\begin{array}{l}\text { Key Concepts } \\
\text { Derived from } \\
\text { the Study }\end{array}$ \\
\hline Pestoff & Public service, & Conceptual & Small group interaction & $\begin{array}{l}\text { Sustainability of } \\
\text { (2014) }\end{array}$ \\
& Collective action and & & improves sustainability of co- & co-production \\
& sustainability of co- & & production. Governments \\
& production & should develop more flexible, & \\
& & service specific and & \\
& & organization specific & \\
& & approaches for promoting co- \\
& & production & \\
& & &
\end{tabular}

\section{Conclusions, Implications and Further Research}

The concepts and gaps identified in this paper would be useful to both practitioners and researchers. For example, management of a bank can train their counter staff (e.g. develop their communication, interpersonal relationship skills) to improve the ability, clarity of task and motivation of the clients so that it can improve the incidence of co-production (Hsieh et al., 2004). Further the studies also show that clients of a firm should be considered as partial employees and hence they should be given training/socialisation programmes by service providers in order to make them better co-producers (Bettencourt et al., 2002; Hsieh et al., 2004). Three levels of customer involvement in co-production (low, moderate, high) have been defined in the studies (Bitner et al., 1997; Hsieh et al., 2004). Based on the service provided by the firm, clients' involvement in co-production may vary. Thus firms must use different strategies to improve co-production based on the service they provide. For example, if a firm provides training (high involvement is needed from trainees), then it has to follow up with the trainees after training in order to increase co-production.

The literature (Chen et al., 2011; Auh et al., 2007; Bendapudi \& Leone, 2003; Knee \& Zukerman, 1996) shows that client's affective commitment and self serving bias affect co-production. Thus firms must try to develop client loyalty in order to improve affective commitment which leads to improved co-production. Moreover, firms could ask its client contact staff to maintain better interpersonal relationships with clients so that self serving bias can be minimised. The co-production literature (Pestoff, 2014, 2012) also reveals that sustainability of co-production is important and a small group with collective action improves the sustainability of co-production. Thus the firms who deal with client groups (e.g. microfinance institutions) could enhance the incidence of co-production by improving its group activities.

This paper also shows that there are many studies made on collaborative co-production but not on collective co-production especially in business management discipline. Moreover this paper identifies gaps in dyadic relationships and contextual factors in co-production literature.

Since there are gaps in co-production literature, in particular areas such as collective coproduction, dyadic relationships and contextual factors, future researchers could focus on these areas. 
For example, there are a limited number of studies made on business discipline focusing on collective co-production. Thus future researchers can shed light on this area. Similarly, focusing on dyadic relationships and contextual factors on co-production, researchers could bring out interesting research findings.

\section{References}

Auh, S., Bell, S. J., McLeod, C. S., \& Shih, E. (2007). Co-production and customer loyalty in financial services. Journal of Retailing, 83(3), 359-370.

Bandura, A. (1997). Self-efficacy: The exercise of control. New York: W.H. Freeman.

Bandura, A. (2001). Social cognitive theory: An agentic perspective. Annual Review of Psychology, 52(1), 1-26.

Bendapudi, N., \& Leone, R. P. (2003). Psychological implications of customer participation in coproduction. Journal of Marketing, 67(1), 14-28.

Bettencourt, L. A. (1997). Customer voluntary performance: Customers as partners in service delivery. Journal of Retailing, 73(3), 383-406.

Bettencourt, L. A., Ostrom, A. L., Brown, S. W. \& Roundtree, R. I. (2002). Client co-production in knowledge-intensive business services. California Management Review, 44(4), 100-128.

Bitner, M., Faranda, W. T., Hubbert, A. R., \& Zeithaml, V. A. (1997). Customer contributions and roles in service delivery. International Journal of Service Industry Management, 8(3), 193-205.

Bowen, D.E. (1986). Managing customers as human resources in service organizations. Human Resource Management, 2(3), 371-383.

Campbell, W. K., \& Sedikides, C. (1999). Self-threat magnifies the self-serving bias: A meta-analytic integration. Review of General Psychology, 3(1), 23-43.

Cepiku, D., \& Giordano, F. (2014). Co-production in developing countries: Insights from the community health workers experience. Public Management Review, 16(3), 317-340.

Chen, J. S., Tsou, H. T., \& Ching, R. K. (2011). Co-production and its effects on service innovation. Industrial Marketing Management, 40(8), 1331-1346.

Cheung, M. F., \& To, W. M. (2011). Customer involvement and perceptions: The moderating role of customer co-production. Journal of Retailing and Consumer Services, 18(4), 271-277.

Etgar, M. (2008). A descriptive model of the consumer co-production process. Journal of the Academy of Marketing Science, 36(1), 97-108.

Firat, A. F. (1991).The consumer in postmodernity. Advances in consumer research. 18(1), 70-76.

Firat. A., Dholakia, N., \& Venkatesh, A. (1995). Marketing in postmodern world. European Journal of Marketing 29(1), 40-56.

Firat, A. F., Shultz, C., \& Clifford, J. (1997). From segmentation to fragmentation. European Journal of Marketing, 31(3/4), 183-207.

Firat, A. F., \& Venkatesh, A. (1993). Postmodernity: The age of marketing. International Journal of Research in Marketing, 10(3), 227-249.

Fitzsimmons, J. A. (1985). Consumer participation and productivity in service operations. Interfaces, 15(3), 60-67.

Ford, R. C., \& Dickson, D. R. (2012). Enhancing customer self-efficacy in co-producing service experiences. Business Horizons, 55(2), 179-188.

Gruen, T. W., Summers, J. O., \& Acito, F. (2000). Relationship marketing activities, commitment, and membership behaviors in professional associations. Journal of Marketing, 64(3), 34-49.

Guo, L., \& Ng, I. (2011). The co-production of equipment-based services: An interpersonal approach. European Management Journal, 29(1), 43-50. 
Hsieh, A. T., Yen, C. H., \& Chin, K. C. (2004). Participative customers as partial employees and service provider workload. International Journal of Service Industry Management, 15(2), 187199.

Hubbert, A. R. (1995), Customer co-creation of service outcomes: Effects of locus of causality attributions (Unpublished doctoral dissertation). Arizona State University, Arizona

Humphreys, A. (2008). Understanding collaboration and collective production: New insights on consumer co-production. Advances in consumer research, 35, 63-66.

Kelley, S. W., Skinner, S. J., \& Donnelly, J. H. (1992). Organizational socialization of service customers. Journal of Business Research, 25(3), 197-214.

Knee, C. R., \& Zuckerman, M. (1996). Causality orientations and the disappearance of the selfserving bias. Journal of Research in Personality, 30(1), 76-87.

Kotze, T. G., \& Du Plessis, P. J. (2003). Students as "co-producers" of education: A proposed model of student socialisation and participation at tertiary institutions. Quality Assurance in Education, 11(4), 186-201.

Lengnick-Hall, C. A. (1996). Customer contributions to quality: A different view of the customeroriented firm. Academy of Management Review, 21(3), 791-824.

Lengnick-Hall, C. A., Claycomb, V., \& Inks, L. W. (2000). From recipient to contributor: Examining customer roles and experienced outcomes. European Journal of Marketing, 34(3/4), 359-383.

Lovelock, C. H., \& Young, R. F. (1979). Look to consumers to increase productivity. Harvard Business Review, 57(3), 168-178.

Lusch, R. F., Vargo, S. L., \& O’Brien, M. (2007). Competing through service: Insights from servicedominant logic. Journal of Retailing, 83(1), 5-18.

Meuter, M. L., Bitner, M. J., Ostrom, A. L., \& Brown, S. W. (2005). Choosing among alternative service delivery modes: An investigation of customer trial of self-service technologies. Journal of Marketing, 69(2), 61-83.

Meyer, J. P. \& Allen, N. J. (1991). A three-component conceplualization of organisational commitment. Human Resource Management Review, 1, 61-98.

Mills, P. K., Chase, R. B., \& Margulies, N. (1983). Motivating the client/employee system as a service production strategy. Academy of Management Review, 8(2), 301-310.

Mills, P. K., \& Morris, J. H. (1986). Clients as 'partial' employees: Role development in client participation. Academy of Management Review, 11(4), 726-735.

Moorthy, S., Ratchford, B. T., \& Talukdar, D. (1997). Consumer information search revisited: Theory and empirical analysis. Journal of Consumer Research, 23(4), 263-277.

Ostrom, E. (1999) Crossing the great divide: Coproduction, synergy, and development. In M. McGinnis (Ed.), Polycentric governance and development: Readings from the workshop in political theory and policy analysis. Ann Arbor, MI: University of Michigan Press.

Parks, R. B., Baker, P. C., Kiser, L., Oakerson, R., Ostrom, E., Ostrom, V., ... \& Wilson, R. (1981). Consumers as coproducers of public services: Some economic and institutional considerations. Policy Studies Journal, 9(7), 1001-1011.

Pestoff, V. (2012). Co-production and third sector social services in Europe: Some crucial conceptual issues. In V. Pestoff, T. Brandsen, \& B. Verschuere (Eds.), New public governance, the third sector and co-production, (pp. 13-34). New York: Routledge.

Pestoff, V. (2014). Collective action and the sustainability of co-production. Public Management Review, 16(3), 383-401.

Peters, C., Bodkin, C. D., \& Fitzgerald, S. (2012). Toward an understanding of meaning creation via the collective co-production process. Journal of Consumer Behaviour, 11(2), 124-135. 
Prahalad, C. K., \& Ramaswamy, V. (2000). Co-opting customer competence. Harvard Business Review, 78(1), 79-90.

Prahalad, C. K., \& Ramaswamy, V. (2002). The co-creation connection. Strategy and Business, 27(2), 50-61.

Prahalad, C. K., \& Ramaswamy, V. (2004). Co-creation experiences: The next practice in value creation. Journal of Interactive Marketing, 18(3), 5-14.

Rice, M. P. (2002). Co-production of business assistance in business incubators: An exploratory study. Journal of Business Venturing, 17(2), 163-187.

Rodie, A. R., \& Kleine, S. S. (2000). Customer participation in services production and delivery. In T. A. Swartz, \& D. Iacobucci (Eds.), Handbook of services marketing and management, (pp.111126). Thousand Oaks, CA: Sage Publications Inc.

Schneider, B., \& Bowen, D. E. (1995). Winning the service game. Boston, MA: Harvard Business School Press.

Schroeder, S. D. (1990). The state of the business incubation industry. Athens, OH: The National Business Incubation Association.

Van Beuningen, J., de Ruyter, K., \& Wetzels, M. (2010). The power of self-efficacy change during service provision: Making your customers feel better about themselves pays off. Journal of Service Research, 14(1), 108-125.

Vargo, S. L., \& Lusch, R. F. (2004). Evolving to a new dominant logic for marketing. Journal of Marketing, 68(1), 1-17.

Vargo S. L., \& Lusch, R. F. (2006). Evolving to a new dominant logic for marketing. In R. F. Lusch \& S. L. Vargo (Eds.), The service dominant logic of marketing (pp. 3-28). New York: M. E. Sharpe.

Verschuere, B., Brandsen, T., \& Pestoff, V. (2012). Co-production: The state of the art in research and the future agenda. Voluntas: International Journal of Voluntary and Nonprofit Organizations, 23(4), 1083-1101.

Wolosin, R. J., Sherman, S. J., \& Till, A. (1973). Effects of cooperation and competition on responsibility attribution after success and failure. Journal of Experimental Social Psychology, 9(3), 220-235. 